\title{
SOCIAL ENTREPRENEURSHIP AND SOCIAL INNOVATION: THEORETICAL DISCOURSE
}

\author{
Lasma Licite ${ }^{1}$, Dr.oec., assistant professor; \\ Gunta Grinberga-Zalite ${ }^{2}$, Dr.oec., associate professor \\ 1,2 Latvia University of Life Sciences and Technologies
}

\begin{abstract}
Lately, international academic interest is evolving around a number of interconnected concepts that intrinsically include two apparently contradictory dimensions: social and economic. Among them, the most visible are the concepts of social entrepreneurship and social innovation, which are closely linked. The aim of the research paper is to clarify the relation between the concepts of social innovation and social entrepreneurship. Within the research, the authors used the following methods: monographic method, the methods of analysis and synthesis as well as the method of scientific induction and deduction. In scope of the research, the authors used scientific literature on social entrepreneurship and social innovation.

The research shows that social entrepreneurship and social innovation are closely interrelated concepts, since social entrepreneurship often creates and promotes social innovation. Social innovation is a mechanism in actual innovation but a social entrepreneur is a driving force for social change. In addition, a significant difference is the fact that social innovation is not necessarily linked to commercial interests, while in social entrepreneurship the involvement in commercial activities is a mandatory precondition to ensure efficient operation of the enterprise and solving of social problems.
\end{abstract}

Keywords: sustainability, social problems, social change.

JEL code: $\mathrm{M} 14, \mathrm{O} 3$

\section{Introduction}

The demand for innovative solutions for social problems is on a continuous rise. While a great progress has been made through technology and improved social services, every improvement raises new challenges, as well creating new problems. Therefore, new and innovative systems and paradigms are highly needed for creating solutions (Irengun, Arikboga, 2015). The field of social innovation turns critical societal problems into opportunities by actively involving the community actors. However, lately, in the international academic debate a discussion is evolving around a number of interconnected concepts, which intrinsically include two apparently contradictory dimensions: social and economic (Lisetchi, Brancu, 2014). Among them, the concepts of social innovation and social entrepreneurship are the two most well-known. The terms "social entrepreneurship" and "social enterprise" are often used interchangeably with the term "social innovation". It is clear, however, that any sophisticated understanding of how novelty transforms complex systems requires great conceptual precision (Westley, Antandze, 2010).

The aim of the research paper is to contribute to clarifying the relation between the two concepts - social innovation and social entrepreneurship. The specific research tasks were: 1) to aggregate theoretical definitions and approaches of the two concepts; 2) to analyse the main characteristic elements of the two concepts; 3 ) to find out and justify the theoretical differences of these concepts. In the research, the authors used the following methods: monographic method (to create a theoretical discussion and interpret research results on the social innovation and social entrepreneurship concepts, which are based on the findings of scientific literature); the methods of analysis and synthesis to separately explore elements of the problem and build interrelationships; the method of scientific induction - to create scientific assumptions and similarities based on separate elements; scientific deduction method - to logically systematize and explain empirical data. In scope of the research, the authors used scientific literature on social entrepreneurship and social innovation. 


\section{The concept of social innovation}

In the academic literature, there is a wide range of approaches to conceptualizing the term "social innovation". One of the first researchers who initiated the use of the concept "social innovation" in the $19^{\text {th }}$ century was Webber who used it to denote social invention. Whereas Schumpeter $(1934 ; 1942)$ defined innovation as a combination of new elements (invention of new goods, methods, raw materials in organization or industry) that is a novelty for the existing economic system. So far, several attempts to structure the field of social innovation have been made, for example by Dedijer (1984), Zapf (1991), Moulaert and Nussbaumer (2005), Pol and Ville (2009), Ruede and Lurtz (2012), Butkeviciene (2009), Dobele (2015) and Surikova, Oganisjana, Grinberga-Zalite (2015). In addition, these categorizations often lack a systematically grounded methodology that covers the social innovation concept in various disciplines at the same time.

Based on theoretical studies, the authors define social innovation as a new, sustainable and effective solution to pressing social problems in the society. As a result of social innovation, social value is created (Dobele, 2015). The definition is based on a fact that important characteristics of social innovation is "newness" (Dawson, Daniel, 2010; Zapf, 1991; Schumpeter, 1942), "introduction of change" (Mahdjoubi, 1997), importance in "solving social problems" (Mulgan et al., 2007; Tanimato, Doi, 2007; Neamtan, 2003), "creation of value or benefit to the whole community" (Khutrakun, 2013) as well as "sustainability and effectiveness' (Phills et al., 2008).

\section{Research results and discussion The concept of social entrepreneurship}

The scientific literature studies reveal that often social innovation concept is used as a synonym to social entrepreneurship. This could be explained by the fact that the currently existing definitions and approaches for explaining social entrepreneurship are rather ambiguous. In a broader sense, with social entrepreneurship we understand the creation of an innovative social value that can take place in both public and private and non-profit sectors (Austin et al., 2006). It can also be an activity that is implemented to solve social problems in an innovative and creative way (Johnson, 2000). Also, Yunus (2007) defines it as a movement and innovative initiative that is aimed to help people. It means that such an activity can be implemented both within a social enterprise and outside it; it can have either economic or non-economic character; and it can be either profit oriented or non-profit oriented activity. Therefore, such explanation leads to the conclusion that social enterprise is the basic element of social entrepreneurship.

In a narrower sense, social entrepreneurship concept is used to denote the process of social business start-ups foundation (Defourny, Nyssens, 2008). Although the main emphasis in this definition is placed on the process, it does not exclude the role of individual in it, as every process includes people, activities and organization (Nadler, Tushman, 1980), and, thus, the processes that take place within a social enterprise are not exclusion. Mair and Marti (2006) have emphasized that social entrepreneurship is, firstly, a process in which a value is created by mutually combining resources. Secondly, the combination of resources is envisaged mainly to explore and use opportunities for social value creation and thus - promotion of social changes or satisfaction of social needs. Thirdly, social entrepreneurship includes supply of a product or service as well as it can be related with foundation of new organizations. Bygrave and Hofer (1991) have pointed out that the process includes all the activities that are connected with the use of opportunities for creation of a social value and social enterprise foundation. It means that social entrepreneurship 
includes the elements that characterize social enterprises and social entrepreneurs. In scope of the current research, social entrepreneurship is defined as a kind of entrepreneurship the priority of which is the creation of social value, which ensures financial self-sufficiency and sustainability (Dobele, 2013).

Thereby, the authors conclude that although social entrepreneur and social innovation concepts are interrelated, they are not identical. By identifying criteria of social innovation and social entrepreneurship, further research will focus on the comparison of these concepts to define their common features and differences.

\section{Analysis of social entrepreneurship and social innovation concepts}

In the previous research works (Dobele, 2013; Surivoka, Grinberga-Zalite, Oganisjana, 2015; Dobele, Grinberga-Zalite, Kelle, 2015), the authors have initiated extensive public discussions and conducted surveys involving various groups of stakeholders, which gave evidence of close integration and synergy effects that exist between these two concepts. Due to the limitations in the volume of the current publication, this analysis is based on a comparison of key elements that are rooted in the two analysed concepts, thus concurrently ensuring a scientific discussion on the theoretic discourse of these concepts and spotting differences between them.

To identify social innovation, the main criteria used are newness or novelty, introduction of change, solving social problems, creation of value or benefit to the whole community, sustainability and effectiveness. While to identify social entrepreneurship, Peattie and Morley (2008) and Edwards (2008) suggest that there are two key criteria: social goal priority and engagement in commercial activities. The comparison of the criteria that characterize social innovation and social entrepreneurship is presented in Table 1.

Newness, novelty. Important characteristic of social innovation is newness. Social innovations can be broadly described as "new ways of doing things, especially new organizational devices, new regulations, new living arrangements that change the direction of social change, attain goals better than older practices, become institutionalized and prove to be worth imitating" (Zapf, 1991). Also, social entrepreneurship often includes the element of novelty (Svirina et al., 2016) that can find its expression in the management of social enterprise, its structure, strategy as well as creation of products or services. Taking into consideration the essence of social innovation, social entrepreneurs often are defined as the "agents" of new markets in those market spheres that are not attractive for private sector. Leadbeater (2007) emphasizes that social enterprises can become a significant source of innovation, especially social innovation. However, it is important to point out that although it is important to use innovative elements in social entrepreneurship to solve social problems and social entrepreneurship itself is characterized as innovative kind of entrepreneurship, the novelty element is still not a mandatory requirement in social entrepreneurship activities (creation of innovative products and services). At the same time, the outcomes of social innovation are regarded as social innovation.

Introduction of change. Social innovation creates "changes in (human) structure and organization" (Simms, 2006), thereby improving the living standards and promoting human resource development (Mahdjoubi, 1997). Also, social innovation is defined as "the guided change process, preferably supported by all involved and affected human beings that creates significant change in existing action structures and conditions in the social system based on ethical value judgements, contents and programmes" (Maelicke, 1987). The scale of change can be 
differentiated - from changes at the micro level to the macro level (Bulut et al., 2013; Khutrakun, 2013).

Characterizing elements of social innovation and social entrepreneurship

\begin{tabular}{|c|c|c|c|}
\hline \multicolumn{2}{|c|}{ Characteristics } & Social innovation & Social entrepreneurship \\
\hline \multirow{5}{*}{ 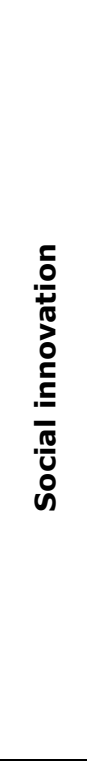 } & $\begin{array}{l}\text { Newness, } \\
\text { novelty }\end{array}$ & $\begin{array}{l}\text { Mandatory precondition to identify } \\
\text { social innovation }\end{array}$ & $\begin{array}{l}\text { Often includes a novelty element; } \\
\text { however, it is not a mandatory } \\
\text { precondition }\end{array}$ \\
\hline & $\begin{array}{l}\text { Introduction of } \\
\text { change }\end{array}$ & $\begin{array}{l}\text { Social innovation is a mechanism, } \\
\text { actual innovation (a product or a } \\
\text { service); } \\
\text { social innovation can take place within } \\
\text { public, private, non-profit sector, or in } \\
\text { the space between them }\end{array}$ & $\begin{array}{l}\text { Social entrepreneur is a driving force } \\
\text { of social changes but not actual } \\
\text { innovation; the source of social } \\
\text { innovation is private sector (social } \\
\text { enterprise) }\end{array}$ \\
\hline & $\begin{array}{l}\text { Solving social } \\
\text { problems }\end{array}$ & $\begin{array}{l}\text { Priority requirement to identify social } \\
\text { innovation }\end{array}$ & $\begin{array}{l}\text { Priority is solving of problems that } \\
\text { are important for society }\end{array}$ \\
\hline & $\begin{array}{l}\text { Creation of the } \\
\text { benefit to the } \\
\text { whole society }\end{array}$ & $\begin{array}{l}\text { Basic requirement is to provide benefit } \\
\text { for the society and there is no financial } \\
\text { gain or loss when it comes to social } \\
\text { innovation }\end{array}$ & $\begin{array}{l}\text { The aim is to provide benefit for the } \\
\text { society, however it needs to be done } \\
\text { in a financially efficient way }\end{array}$ \\
\hline & $\begin{array}{l}\text { Sustainability } \\
\text { and } \\
\text { effectiveness }\end{array}$ & $\begin{array}{l}\text { Sustainability does not depend on } \\
\text { social innovator }\end{array}$ & $\begin{array}{l}\text { Sustainability is connected with } \\
\text { economic activity of a social } \\
\text { enterprise, which ensures the } \\
\text { solution to a social problem in a long- } \\
\text { term period }\end{array}$ \\
\hline \multirow{2}{*}{ 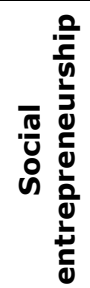 } & $\begin{array}{l}\text { Commercial } \\
\text { motive }\end{array}$ & $\begin{array}{l}\text { It not necessarily to be linked with } \\
\text { commercial interests, although social } \\
\text { innovation does not exclude it }\end{array}$ & $\begin{array}{l}\text { The involvement in commercial } \\
\text { activities is mandatory }\end{array}$ \\
\hline & Social goal & $\begin{array}{l}\text { Important precondition to define social } \\
\text { innovation }\end{array}$ & Priority in social entrepreneurship \\
\hline
\end{tabular}

Social entrepreneurship also causes changes in society, as it is oriented towards elimination of market imperfections (especially, to solve the problems of minorities or other specific society groups) (Evers et al., 2004) or to solve government problems related with providing of public services (Mulgan, Landry, 1995; Leadbeater, 1997). Social entrepreneurs create social innovation and changes in different areas including education, health, environment and business development (Haugh, 2005). However, the most important difference in the use of these concepts regarding the management of changes lies in the fact that social entrepreneurs very often create and promote social innovation and changes in society, while social innovation is a mechanism, actual innovation (e.g. micro-credits), but social entrepreneur is a driving force of social changes. Moreover, the source of social innovation in the case of social entrepreneurship is a private sector (social enterprise), whereas social innovation can take place within public sector or within private sector, either for-profit or non-profit, or in the space between them.

Solving social problems. Several researchers emphasize the importance of social innovation in solving social problems. It is defined as a new idea that works to meet pressing unmet needs and improve peoples' lives (Mulgan et al., 2007; Tanimato, Doi, 2007; Neamtan, 2003). The primary purpose of social entrepreneurship is also to solve problems that are important for the society, i.e. the aim of social enterprise is not gaining the profit for its owners but solving of different social problems (e.g. in education, healthcare, availability of technologies, environmental pollution, poverty elimination). Entrepreneurship can address national, regional or local social 
challenges and its offered solution is important and accepted by society. The problem to be solved can also be determined by planning documents and regulations, included in the government agenda or it can be an issue that is topical for society and nobody else deals with it. To sum it up, solving of social problems is a unified criterion for identifying of the two analysed concepts.

Creation of the benefit to the whole society. People who engage in a social innovation process do not intend to take benefits for themselves; instead, they try to create valuable social innovation for the whole community. It is possible for everyone to reap such a benefit. There is no financial gain or loss when it comes to social innovation (Khutrakun, 2013). Also in social entrepreneurship, one of the basic objectives is to act for the benefit of the whole society or some of its groups. The distinctive feature of a social enterprise is its willingness to promote social responsibility in the local community. For instance, the aim of a social enterprise can be to create a social benefit in a particular industry in the interests of local community or whole society, labour integration, and improvement of the target group's work and social skills (Defourny, Nyssens, 2008). Several researchers of social entrepreneurship have claimed that social entrepreneurs often create social innovation that is aimed at improving the quality of life, especially of socially vulnerable groups (Certo, Miller, 2008; Shaw, Carter, 2007; Doherty et al., 2009; Haugh, 2005). Therefore, it can be concluded that the aim of social entrepreneurship is to provide benefit for society by doing it in a financially efficient way.

Sustainability and effectiveness. Phills et al. (2008) define social innovation as a novel solution to a social problem that is more effective, sustainable, and for which the value created accrues primarily to society as a whole. It can be concluded that important element for social innovation is sustainability and effectiveness. Whereas in case of social innovation, sustainability not always is connected with ensuring financial sustainability from the side of social innovator, while in case of social entrepreneurship sustainability is closely related with financial efficiency.

Commercial motive. Social innovation should not necessarily be connected with commercial interests, although social innovation does not exclude this aspect (Murray et al., 2010). Social innovation is primarily oriented towards systematic changes (Westley, Antadze, 2010), while one of the basic criteria of social entrepreneurship is involvement in commercial activities to reach efficiently its social objective. Social enterprise produces goods that are demanded in the market and provides necessary services. Such enterprise in its activity uses efficient and viable methods to ensure its existence in a long term.

As indicated in the European Economic and Social Committee's report of 11 October 2011 to the European Commission, social enterprises are participants of economic area that produce goods, services and often have a strong element of social innovation. This finding leads to conclusion that commercial motive is one of the most important differences between social innovation and social entrepreneurship. Also, Westley and Antandze (2010) have claimed that "social innovation does not necessarily involve a commercial interest, though it does not preclude such interest".

Social goal priority. Social innovation is based on social motive (Khutrakun, 2013). Social innovation is about the satisfaction of basic needs and changes in social relations within empowering social processes; it is about people and organisations who are affected by deprivation or lack of quality in daily life and services, who are disempowered by lack of rights or authoritative decision-making, and who are involved in agencies and movements favouring social innovation (Moulaert, Nussbaumer, 2005). The priority of social enterprise is its social aim or solving of social or environmental problems that are important for society, whereas profit is a subordinated aspect 
(Pearce, 2003; Phillips, 2006; Chell, 2007; Mair, Marti, 2006; Peredo, McLean, 2006; Borzaga, Tortia, 2005; Dees, 2001). Social enterprises are characterized by their awareness of strong social values and mission, which are often aimed at enhancing the capacity of local community. Social aims can be directed towards satisfaction of particular social needs, which require a specific way how this problem could be solved (Alvord et al., 2004; Dees, 2001), or they could be directed towards improvement of society's situation (Peredo, McLean, 2006). To sum it up, social motive and solution of society's problems are a unifying aspect in the use of the concepts "social innovation" and "social entrepreneurship".

\section{Conclusions}

The concepts of social innovation and social entrepreneurship are indeed closely linked because the priority of social innovation and social entrepreneurship is social aim - solving of social problems and providing of benefits to the wider society but not particular its individuals. Owing to this reason, social enterprises can often become a significant source of social innovation.

Nevertheless, there are several substantial differences between these concepts. Firstly, social entrepreneurship is a social innovation in itself; thus, it is innovating the concept of entrepreneurship adding social value. However, at the same time social enterprise should not necessarily create an innovative product or service, although it is advisable. Secondly, social entrepreneurs very often cause and promote social innovations and changes in society. Hence, social innovation is a mechanism, actual innovation but social entrepreneur is a driving force of social changes. Thirdly, the source of social innovation in the case of social entrepreneurship is private sector (social enterprise) but social innovation can take place within public, private, non-profit sector, or in the space between them. Fourthly, a significant aspect of social innovation and social entrepreneurship is to ensure sustainability and effectiveness, yet in case of social innovation, sustainability not always is connected with provision of financial sustainability from the side of social innovator, while in case of social entrepreneurship, it is a mandatory requirement to ensure efficient operation of the enterprise alongside with solving a social problem. Moreover, social innovation should not necessarily be connected with commercial interests, although does not exclude this aspect, while for social entrepreneurship producing of goods or providing of services is a significant precondition to ensure economic viability of the social enterprise.

\section{Acknowledgements}

The paper was supported by the National Research Programme 5.2 "Economic Transformation, Smart Growth, Governance and Legal Framework for the State and Society for Sustainable Development - a New Approach to the Creation of a Sustainable Learning Community (EKOSOCLV)". The research was conducted within the project 5.2.7 "Involvement of the society in social innovation for providing sustainable development of Latvia" of the National Research Program EKOSOC-LV.

\section{References}

1. Alvord, S.H., Brown, L.D., Letts, C.W. (2004). Social Entrepreneurship and Societal Transformation. Journal of Applied Behavioural Science, 40(3), pp. 260-282. doi: 10.1177/0021886304266847.

2. Austin, J., Stevenson, H., Wei-Skillern, J. (2006). Social and Commercial Entrepreneurship: Same, Different, or Both? Entrepreneurship Theory and Practice, 30(1), pp. 1-22. doi: 10.1111/j.1540-6520.2006.00107.x

3. Borzaga, C., Defourny, J. (2001). The Emergence of Social Enterprise. London: Routledge. 386 p.

4. Bulut, C., Eren, H., Halac, D.S. (2013). Social Innovation and Psychometric Analysis. Procedia - Social and Behavioral Sciences, 82, pp. 122-130. doi: 10.1016/j.sbspro.2013.06.235. 
5. Butkeviciene, E. (2009). Social Innovations in Rural Communities: Methodological Framework and Empirical Evidence. Social Sciences, 1(63), pp. 80-88.

6. Bygrave, W.D., \& Hofer, C.W. (1991). Theorising about Entrepreneurship. Entrepreneurship Theory and Practice, 16(2), pp. 3-22.

7. Certo, S.T., Miller, T. (2008). Social Entrepreneurship: Key Issues and Concepts. Business Horizons, 51(4), pp. 267-271. doi: 10.1016/j.bushor.2008.02.009.

8. Chell, E. (2007). Social Enterprise and Entrepreneurship: towards a Convergent Theory of the Entrepreneurial Process. International Small Business Journal, 25(1), pp. 5-26. doi: $10.1177 / 0266242607071779$.

9. Dawson, P., Daniel, L. (2010). Understanding social innovation: a provisional framework. International Journal of Technology Management, 51(1), pp. 9-21. doi: 10.1504/IJTM.2010.033125.

10. Dedijer, S. (1984). Science - and Technology-related Social Innovations in UNCSTD National Papers. In C.G. Heden \& A. King (Eds.), Social innovations for development (pp. 57-92). Oxford, New York: Pergamon Press.

11. Dees, J.G. (2001) The Meaning of "Social Entrepreneurship". Retrieved: https://entrepreneurship.duke.edu/news-item/the-meaning-of-social-entrepreneurship/. Access: 31 May 2017.

12. Defourny, J., Nyssens, M. (2008). Social Enterprise in Europe: Recent Trends and Developments. Social Enterprise Journal, 4(3), pp. 202-228. doi: 10.1108/17508610810922703.

13. Dobele, L. (2013). Social Entrepreneurship Development Possibilities in Latvia. Jelgava: LLU, pp.55-63.

14. Dobele, L. (2015). Factors which Influence the Development of Social Innovation in Latvia. Marketing and sustainable consumption. New dimensions in the development of society, p. 40, pp. 226-238.

15. Dobele, L., Grinberga-Zalite, G., Kelle, L. (2015). Sustainable Economic Development: Scenarios for Promotion of Social Innovation in Latvia. Journal of Security and Sustainability Issues: International Entrepreneurial Perspectives and Innovative Outcomes. - Vol.5 (2) (2015), pp.149-158.

16. Doherty, B., Foster, G., Mason, C., Meehan, J., Meehan, K., Rotheroe, N., Royce, M. (2009). Management for Social Enterprise. London: Sage. 246 p.

17. Edwards, M. (2008). Just Another Emperor? The Myths and Realities of Phylanthrocapitalism. New York: A Network for Ideas \& Action. $106 \mathrm{p}$

18. Evers, A., Laville, J.L., Borzaga, C., Defourny, J., Lewis, J., Nyssen,s M., Pestoff V. (2004). Defining the Third Sector in Europe. In A. Evers, \& J.L. Laville (Eds.). The third sector in Europe (pp. 11-42). London: Edward Elgar.

19. Haugh, H. (2005). A Research Agenda for Social Entrepreneurship. Social Enterprise Journal, 1(1), pp. 1-12. doi: $10.1108 / 17508610580000703$.

20. Irengun, O., Arikboga, S. (2015). The Effect of Personality Traits on Social Entrepreneurship Intentions: a Field Research. Procedia - Social and Behavioral Sciences, p. 195, 1186-1195. doi: 10.1016/j.sbspro.2015.06.172.

21. Johnson, S. (2000). Literature Review on Social Entrepreneurship. Retrieved: https://www.researchgate.net/publication/246704544_Literature_Review_Of_Social_Entrepreneurship. Acce ss: 31 May 2017.

22. Khutrakun, A. (2013). Process and Dynamics of Social Innovation: Case Studies of Local Initiatives in Northern Thailand. Japan Social Innovation Journal, 3(1), pp. 12-18. doi: 10.12668/jsij.3.12.

23. Leadbeater, C. (2007). What are the Future Scenarios for Social Enterprise? Social Enterprise. Think Pieces: Outline Proposals.

24. Lisetchi, M., Brancu, L. (2014). The Entrepreneurship Concept as Subject of Social Innovation. Procedia Social and Behavioral Sciences, p. 124, pp. 87-92. doi: 10.1016/j.sbspro.2014.02.463.

25. Maelicke, B. (1987). Soziale Arbeit als soziale Innovation. Veranderungsbedarf u. Innovationsstrategien. Weinheim: Juventa-Verl. 264 p.

26. Mahdjoubi, D. (1997). The Mapping of Innovation. Retrieved: http://www.ischool.utexas.edu/ darius/map_inov.pdf. Access: 31 May 2017.

27. Mair, J., Marti, I. (2006). Social Entrepreneurship Research: a Source of Explanation, Prediction, and Delight. Journal of World Business, 41(1), pp. 36-44. doi: 10.1016/j.jwb.2005.09.002.

28. Moulaert, F., Nussbaumer, J. (2005). The Social Region. Beyond the territorial dynamics of the learning economy. European Urban and Regional Studies, 12(1), pp. 45-64. doi: 10.1177/0969776405048500.

29. Mulgan, G., Landry, L. (1995). The Other Inivisible Hand: Remaking Charity for the 21st Century. London: Demos/Comedia, $121 \mathrm{p}$.

30. Mulgan, G., Tucker, S., Ali, R., Sanders, B. (2006). Social Innovation: What It Is, Why It Matters and How It can be Accelerated. London: The Young Foundation. Retrieved: http://eureka.sbs.ox.ac.uk/761/1/Social_Innovation.pdf . Access: 31 January 2018.

31. Murray, R., Caulier-Grice, J., Mulgan, G. (2010). The Open Book of Innovation. The Young Foundation \& NESTA. 222 p.

32. Nadler, D.A., Tushman, M.L. (1980). A Congruence Model for Organizational Assessment. In E.E. Lawler D.A. Nadler, \& C. Cammann (Eds.), Organizational Assessment: Perspectives on the Measurement of Organizational Behavior and the Quality of Work Life (pp. 261-278). New York: Wiley. 
33. Neamtan, N. (2003). Non-profit Sector and Evaluation: the State of Play in Quebec. In OECD (Ed.), The Non-Profit Sector in a Changing Economy (pp. 221-238). Paris: OECD.

34. Pearce, J. (2003). Social Enterprise in Anytown. London: Calouste Golbenkian Foundation. 144 p.

35. Peredo, A.M., McLean, M. (2006). Social Entrepreneurship: a Critical Review of the Concept. Journal of World Business, 41(1), pp. 56-65. doi: 10.1016/j.jwb.2005.10.007.

36. Peattie, K., Morley, A. (2008) Social Enterprises: Diversity and Dynamics, Contexts and Contributions: Research Monograph. Social Enterprise Coalition/ESRC: Swindon. Retrieved: http://orca.cf.ac.uk/30775/1/SE \%20Monograph \%20Published.pdf. Access: 31 January 2018.

37. Phillips, M. (2006). Growing Pains: the Sustainability of Social Enterprises. Entrepreneurship and Innovation, 7(4), pp. 221-230. doi: 10.5367/000000006779111648.

38. Phills, J.A., Deiglmeier, K., Miller, D.T. (2008). Rediscovering social innovation. Stanford Social Innovation Review, 43, pp. 34-43.

39. Pol, E., Ville, S. (2009). Social Innovation: Buzz Word or Enduring Term? Journal of Socio-Economics, p. 38, pp. 878-885. doi: 10.1016/j.socec.2009.02.011

40. Ruede, D., Lurtz, K. (2012). Mapping the Various Meanings of Social innovation: towards a Differentiated Understanding of an Emerging Concept. EBS Business School Research Paper Series 12-03, p. 52.

41. Schumpeter, J.A. (1942). Capitalism, Socialism and Democracy. New York: Harper \& Row. Retrieved: http://cnqzu.com/library/Economics/marxian \%20economics/Schumpeter, \%20JoesephCapitalism, \%20Socialism \%20and \%20Democracy.pdf. Access: 31 January 2018.

42. Schumpeter, J.A. (1934). The Theory of Economic Development. Cambridge: Harvard University Press. Retrieved: http://compaso.eu/wpd/wp-content/uploads/2013/01/Compaso2012-32-Croitoru.pdf. Access: 31 January 2018.

43. Shaw, E., Carter, S. (2007). Social Entrepreneurship: Theoretical Antecedents and Empirical Analysis of Entrepreneurial Processes and Outcomes. Journal of Small Business and Enterprise Development, 14(3), pp. 418-434. doi: 10.1108/14626000710773529.

44. Simms, J.R. (2006). Technical and Social Innovation Determinants of Behaviour. Systems Research and Behavioral Science, 23(3), pp. 383-393. doi: 10.1002/sres.734.

45. Surikova, S., Oganisjana, K., G. Grinberga-Zalite (2015). The Role of Education in Promoting Social Innovation Processes in the Society, Society. Integration. Education : Proceedings of the International Scientific Conference 2015, Rezekne Higher Education Institution. Faculty of Education and Design. Rezekne, Vol.4, p. 233-243. DOI: 10.17770/sie2015vol4.337

46. Svirina, A., Zabbarova A., \& Oganisjana K. (2016). Implementing Open Innovation Concept in Social Business. Journal of Open Innovation: Technology, market, and Complexity, 2:20. doi: 10.1186/s40852016-0046-8.

47. Tanimoto, K., Doi, M. (2007). Social Innovation Cluster in Action: a Case Study of the San Francisco Bay Area. Hitotsubashi Journal of Commerce and Management, 41(1), pp. 1-17. doi: 10.15057/14619.

48. Westley, F., Antandze, N. (2010). Making a Difference: Strategies for Scaling Social Innovation for Greater Impact. The Innovation Journal: The Public Sector Innovation Journal, 15(2), pp. 2-19.

49. Yunus, M. (2007). Creating a World without Poverty. Social Business and the Future of Capitalism. New York: United States of America. Retrieved: http://www.globalurban.org/GUDMag08Vol4Iss2/Yunus.pdf. Access: 31 January 2018.

50.Zapf, W. (1991). The Role of Innovations in Modernization Theory. International Review of Sociology, 2(3), pp. 83-94. doi: 10.1080/03906701.1991.9971098. 